\title{
Just Transition and Workers' Rights in the Global South: The Recent Argentine and Chilean Nationally Determined Contributions
}

\author{
Mauro Pucheta ${ }^{1, *}$, César Álvarez Alonso ${ }^{2}$ and Pedro Silva Sánchez ${ }^{3}$ \\ 1 Law Department, School of Law, Social and Behavioural Sciences, Faculty of Business and Social Sciences, \\ Penrhyn Road Campus, Kingston University London, Kingston upon Thames KT1 2EE, UK \\ 2 IE Law School, Business Area Campus, IE University, 28046 Madrid, Spain; cesara@faculty.ie.edu \\ 3 Escuela de Derecho Público, Facultad de Derecho, Universidad Alberto Hurtado, 8320000 Santiago, Chile; \\ pesilva@uahurtado.cl \\ * Correspondence: m.pucheta@kingston.ac.uk
}

check for

updates

Citation: Pucheta, M.; Álvarez

Alonso, C.; Silva Sánchez, P. Just

Transition and Workers' Rights in the

Global South: The Recent Argentine and Chilean Nationally Determined Contributions. Sustainability 2021, 13, 9616. https://doi.org/10.3390/ su13179616

Academic Editor: Wadim Strielkowski

Received: 1 April 2021

Accepted: 9 August 2021

Published: 26 August 2021

Publisher's Note: MDPI stays neutral with regard to jurisdictional claims in published maps and institutional affiliations.

Copyright: (C) 2021 by the authors. Licensee MDPI, Basel, Switzerland. This article is an open access article distributed under the terms and conditions of the Creative Commons Attribution (CC BY) license (https:// creativecommons.org/licenses/by/ $4.0 /)$.

\begin{abstract}
Just transition tackles the consequences of a transition to a zero-carbon economy while addressing the issues of equity and justice so that nobody is left behind. It is a roadmap that informs the action of states towards sustainable development. The paper focuses on how Argentina and Chile, with a high percentage of informality in their economies and their labour markets, have embedded just transition into their legal orders through the submission of Nationally Determined Contributions (NDCs). The analysis of both experiences to protect workers is based upon three aspects: the Global South perspective; the 2015 ILO guidelines; the historical step that Argentina and Chile have reached in the submission of their second NDCs since these are the first Latin American countries to have expressly included just transition and work in their NDCs. After a thorough analysis, the paper concludes that this seems to be a promising first step that requires, nonetheless, a global approach in order to protect the environment and ensure that no one is left behind.
\end{abstract}

Keywords: just transition; workers' rights; Paris agreement; informal economies; Chile; Argentina; Latin America; Global South; Sustainable Development Goals (SDGs); Nationally Determined Contributions (NDCs)

\section{Introduction}

Environmental protection and jobs are inherently related. Originally, the protection of the planet seemed contradictory with the development of industrial policies that would create new jobs but, at the same time, further pollute. Environmentalists considered that workers saw nature as an exploitable resource [1]. There was a tension between social democracy and environmentalism, which considered that environmental protection was a brake to economic growth, which was cast as a solution to unemployment and precariousness [2].

The climate crisis requires urgent action to ensure that disadvantaged workers and communities, which are usually hit the hardest, are protected. Recent studies demonstrate that there is a link between the increase in $\mathrm{CO}_{2}$ emissions and inequality in society [3]. It is crucial to provide alternative solutions for workers in fossil fuel-dependent regions; otherwise, there is a high risk that these regions could witness serious economic turmoil that might result in political unrest and degradation of the social order [4].

In this context, just transition plays a crucial role in developing and strengthening the synergies between labour and nature. It constitutes a roadmap that informs the action of countries, social partners as well as international organisations to adapt societies and economies towards sustainable development. Just transition involves the adjustment of production systems and the adoption of mitigating measures to ease the impact on the formal and informal labour market. Nonetheless, just transition should not only be 'about 
creating a safety net for precarious workers in declining sectors ... it is [also] about getting workers and frontline communities to engage in the environmental debate' [5]. Workers and unions, as well as civil society at large, can participate in the elaboration of policies towards a more sustainable development.

Beyond this nature-labour relationship, just transition involves another dimension that begs to be explored, which is its global aspect. Although the fight against climate change is a global enterprise, national solutions are usually preferred to ensure the safety of the planet. However, countries have different economic, social, political, and cultural realities. The protection of workers' rights in a context of just transition requires a Global South perspective, in which the high rates of informality and precariousness make it extremely challenging to adopt just transition measures that encompass everybody. Furthermore, in a post-pandemic world, countries in the Global South, which are engulfed in economic and sanitary crises, are probably more concerned about economic recovery than the protection of the environment. This brings another layer of difficulty to the relationship between just transition and workers' rights, particularly because many of these countries are sitting on generous natural resources.

In this context, this paper aims to explore how two Global South countries, Argentina and Chile, have embedded the protection of workers' rights in their just transition commitments, specifically in their recent Nationally Determined Contributions (hereinafter 'NDCs') [6]. This requires a brief examination of the features and challenges that Argentine and Chilean workers may face, as well as the international framework in which the concept of just transition has been developed.

This article begins by stating the methodology adopted. It then examines the challenges that the South American workforce may face in a context of green policies and just transition. This paper also explores the international framework in which the concept of just transition has been developed, the 2015 ILO Guidelines for a Just Transition (hereinafter '2015 Just Transition Guidelines') [7] are the unavoidable starting point of any analysis.

Once the background is explored, this paper examines the content of the recent second NDCs submitted by Chile in March 2020 [8] (hereinafter 'Chilean NDCs 2020') and Argentina in December 2020 [9] (hereinafter 'Argentine NDCs 2020'), which have introduced just transition into their national legal orders [10]. It then studies the governance adopted by both countries to ensure that comprehensive and consistent policies are adopted. Furthermore, it briefly explores the role of social actors in the promotion and implementation of just transition policies. It concludes that the second NDCs are in line with the 2015 Just Transition Guidelines, and they constitute a crucial first step in the inclusion of just transition in their domestic legal orders and may reinforce workers' protection when implementing policies that aim to protect the environment.

\section{Methodology}

This paper explores the following research question: does the recent Argentine and Chilean NDCs meet the standards required by the international legal framework, particularly the 2015 Just Transition Guidelines? More specifically, this paper aims to examine whether their content is in line with these guidelines and the role of unions as institutional bodies in this transition. To answer this question, this article adopts two traditional legal methodologies. Firstly, legal doctrine, or black letter, focuses on the letter of the law. It is 'a mainly hermeneutic discipline, with also empirical, argumentative, logical and normative elements' [11]. The doctrinal method 'involves rigorous analysis and creative synthesis' of both primary sources, that is the relevant international and national legal frameworks, and secondary sources, that is the relevant academic legal literature [12]. It has been argued that one of its major shortcomings has been the limited reference to context. To overcome one of these flaws, this paper explores how trade unions have contributed to just transition beyond their institutional roles.

The analysis of both the Argentine and Chilean experiences in ensuring the protection of workers' rights, in the context of just transition, from a legal perspective is based upon 
an examination of the second NDCs presented by Chile in March 2020 and Argentina in December 2020. This constitutes a historical step because they are the first Latin American countries that have embedded the concept of just transition into their domestic legal orders. To understand whether these new NDCs meet the standards set by the main international legal instruments, it is necessary to touch upon the UNFCCC, the Paris Agreement, and analyse the 2015 Just Transition Guidelines.

Secondly, this paper adopts a comparative legal methodology. Comparative law studies have contributed to unpack the different values pursued by different legal systems [13]. This is useful to understand how different legal orders implement similar international law measures.

Similarity of units of comparison is one of the major challenges of a comparative analysis. The study of the Argentine and Chilean experiences is not an arbitrary choice whatsoever. In this global era, the discipline of law 'needs to broaden its reach to take more account of non-Western legal traditions, a wider range of legal phenomena, and different levels of normative and legal relations and ordering' (Twining, General Jurisprudence: Understanding Law from a Global Perspective (CUP 2009) 56). Both countries embody the challenges that many nations may face in the near future. They are middle-income countries sitting on generous natural resources that they would like to exploit to strengthen their economies. Their relatively high percentage of informal work, as well as their sometimes deficient administrations, make the implementation of just transition policies a challenging task. Both countries have also recently designed an incipient green agenda that includes just transition as one of their main goals.

\section{The Challenges for the Workforce's Just Transition in South America}

The debate and the way to approach the 'just transition' phenomenon differs in a significant manner depending on which countries and regions are taken into consideration. Rosemberg emphasises the importance of, and the need for, considering the Global South when developing just transition policies [14]. That being said, there seems to be an agreement that employment should be the epicentre of its action in order for no one to be left behind in this process [15].

The Latin America-Caribbean (hereinafter 'LAC') region is particularly vulnerable to the effects of climate change. This is largely due to factors such as the strong dependence on natural resources. From a labour perspective, the expected increase in the frequency, severity, and intensity of natural disasters may lead to significant loss of jobs and productivity [16]. Therefore, decisive adaptation measures must be taken to reduce damages. Their cost will be only a fraction of the long-term cost of inaction [17].

However, the transition towards greener economies implies significant structural changes whose immediate impact on labour can be severe. That being said, it may also present several opportunities for decent and green job creation, which aims to guarantee as highlighted by the ILO, a fair income, security in the workplace and social protection for families, better prospects for personal development and social integration, freedom for people to express their concerns, organise and participate in the decisions that affect their lives and equality of opportunity and treatment for all women and men. Here is where just transition and green jobs become relevant as guiding notions for environmental and employment policy makers. If measures like the closure of coal-fired power plants are implemented along with these mechanisms, those possible negative impacts may be reduced. This is not an easy task, particularly given the complexities of the LAC. However, this may constitute an opportunity for the region, too. The ILO predicts that energy decarbonisation processes have the potential to create 15 million new green jobs [18].

The historical economic dependence on natural resources is another aspect to consider. The economic growth, and thus labour market in the region, heavily relies on the exploitation and exportation of raw materials, such as metal, hydrocarbons, and food [19]. This remains one of the biggest challenges of the region because some countries, such as Argentina, have entered into what is called the 'fourth-generation' of extractivist processes, 
which are linked to the production of unconventional hydrocarbons via fracking [20]. To achieve a just transition, states' environmental initiatives that aimed at limiting the exploitation of natural resources must assess their potential negative consequences on the labour market and minimise them. For instance, countries may implement policies that ensure that affected workers would either be reskilled and relocated to green jobs, or they would receive a fair compensation if they were to lose their jobs.

Another major complexity is the high rates of labour informality. Informal employment includes people that are employed, but do not have social protection, labour rights, or are not covered by domestic labour legislation. Informality in Latin America rates up to $50 \%$ of the total workforce (Argentina's 2020 informality rate was 35.8\% [21], whilst Chile was $26.5 \%$ [22]). This group is mostly composed of young workers, mainly women and vulnerable groups [23]. In 2021, due to the COVID-19 outbreak the situation only got worse [24]. Informality turns just transition into an even greater challenge. This is particularly true in countries that are heavily dependent on their agricultural sectors and natural resources, such as Argentina, because informal and precarious workers are most likely to lose their jobs. Measures usually taken to achieve this goal include incentives to attract green businesses that would create new jobs, along with the implementation of reskilling training programmes on green jobs for those workers who have lost their jobs. If that is not feasible, they may also include the possibility to take early retirement or the payment of compensation, all of which usually is negotiated with the relevant trade unions. None of these measures, at first glance, would be easy to apply to informal workers.

Finally, another challenge is related to extreme poverty and income inequality, which is the highest in the world. In 2018, $80 \%$ of the region's income was concentrated in $7 \%$ of the population. Inequality affects the most vulnerable populations, such as indigenous people, women, and youth that face very high rates of unemployment. There are also flaws in the training systems. The percentage of workers receiving some type of training averages around $15 \%$, considerably below the $56 \%$ average observed in OECD countries. Moreover, skills training programmes are usually aimed at people with higher levels of initial education and formal full-time employment, leaving aside the most vulnerable. This perpetuates and amplifies inequalities [25]. This constitutes a further challenge in the shift to a greener economy.

Just transition may not only respond to the needs of those who lose their jobs but may also generate new opportunities of decent work and quality jobs for those currently unemployed. As recently stated by the Special Rapporteur on extreme poverty and human rights, Olivier De Schutter, to be just, the transition must not only protect workers and communities likely to be affected by the ecological transformation, but also 'open up new opportunities and strengthen the rights of people living in poverty' [26].

\section{Just Transition and Workers' Rights on the Global Stage}

\subsection{Just Transition: ILO Guidelines}

The ILO started considering the concept of just transition in the first decade of the 2000s [27]. However, it was not until 2015 when the Governing Body of the ILO adopted the 2015 Just Transition Guidelines. This has been further supplemented by the 'ILO Centenary Declaration for the Future of Work' adopted in 2019 by the International Labour Conference, where the ILO assumed the commitment to 'direct its efforts to [ ... ] ensuring a just transition to a future of work that contributes to sustainable development in its economic, social and environmental dimensions' (Section II.2.(i)).

Although they are non-legally binding instruments, they constitute the ILO framework that guides Member States' plans. The 2015 Just Transition Guidelines constitute the main just transition instrument. They aim at supporting progress towards a low-carbon economy. They are both a policy framework and a practical tool to help countries to ensure just transition. They also promote social protection and creation of decent jobs at a largescale. Moreover, they argue that transition to environmentally and socially sustainable 
economies, if well implemented, can become a strong driver of job creation, social justice, and poverty eradication.

The 2015 Just Transition Guidelines assume that sustainable development is only possible through the active engagement of the world of work. Sustainable development has three equally important pillars that are interrelated-economic, social, and environmental. These guidelines acknowledge that greening of economies presents major challenges, but also several opportunities to achieve social objectives. It has the potential to be a new engine of growth, both in developed and developing economies. It can also be a net generator of decent and green jobs that can contribute significantly to the eradication of poverty and to a higher degree of social inclusion. The greening of economies may enhance the ability to manage natural resources sustainably, increase energy efficiency, and reduce waste, while addressing inequalities and enhancing resilience. The greening of jobs and the promotion of new green jobs, both in traditional and emerging sectors, may certainly foster a competitive, low-carbon, environmentally sustainable economy. It may also develop patterns of sustainable consumption and production and contribute to the fight against climate change. More importantly, transitions to environmentally and socially sustainable economies may become a strong driver of job creation, job upgrading, social justice, and poverty eradication.

The ILO estimates that the overall transition process to a green economy, which is considered mandatory for the fulfilment of the long-term goal of the 2015 Paris Agreement (i.e., to keep the increase in global average temperature to less than $2{ }^{\circ} \mathrm{C}$ above pre-industrial levels), may lead to job losses of around 6 million by 2030. Nonetheless, the shift to a greener economy is expected to trigger the creation of another 24 million jobs by 2030 . This net increase of approximately 18 million jobs across the world may be the result of the adoption of sustainable practices, including changes in the global energy matrix, the projected growth in the use of electric vehicles, and higher performance in energy efficiency in existing and future buildings. To ensure a just transition, the promotion of the green economy must be, therefore, accompanied by policies that facilitate the reallocation of workers, advance decent work, offer local solutions and support displaced workers [28].

These guidelines provide certain key principles that should inform the transition towards sustainable economies and societies. When elaborating their just transition strategies, States should create a set of coherent policies based on social dialogue and respect for fundamental rights, which pays particular attention to the gender dimension. They should aim to maximise the creation of decent work and sustainable industries and minimise the destruction of jobs. They should also promote the creation of green jobs and provide support to workers that lose their jobs and the affected communities. In other words, environmental policies must be implemented with other measures that aim at promoting the creation of decent work, and if applicable, foresee their impact in the world of work, job losses, and environmental displacement. These impacts, in turn, should be minimised by a strong and adequate social protection and the promotion of the development of job skills and job retraining. These policies and measures must, from their discussion to their adoption, be based on social dialogue, which involves all the relevant stakeholders i.e., governments, employers, workers, academia, NGOs, and other members of the civil society.

\subsection{Dynamic Differentiation in the Paris Agreement}

The Paris Agreement has become an important milestone for the understanding of just transition at the international level. It is true that parties only '[took] into account the imperatives of a just transition of the workforce and the creation of decent work and quality jobs in accordance with nationally defined development priorities' [29] in the Preamble of the treaty-which is not legally binding. However, NDCs may play a significant role in this regard. They are the most significant mitigation legal obligations enshrined in the Paris Agreement for Member States. To meet the treaty's long-term goal of holding the increase in the global average temperature well below $2{ }^{\circ} \mathrm{C}$ above pre-industrial levels [30], each State Party must prepare, communicate, and update successively every five years the 
NDCs they intend to achieve [31]. NDCs are a best endeavours obligation (rather than an obligation to achieve results) to which the relevant State Party is legally bound under the Agreement [32]. Despite this relatively soft law nature, the inclusion of just transition in the NDCs of a given state may turn its achievement into a legal obligation.

International law has traditionally recognised the equality of sovereign states. However, political, social, economic, and cultural elements make states differ significantly. Differential treatment is one of the key aspects of international environmental law [33]. Principle 7 of the 1992 Rio Declaration states that:

'In view of the different contributions to global environmental degradation, States have common but differentiated responsibilities. The developed countries acknowledge the responsibility that they bear in the international pursuit of sustainable development in view of the pressures their societies place on the global environment and of the technologies and financial resources they command'. [34]

This was further developed in the UNFCCC where the principle of 'common but differentiated responsibilities and respective capabilities' (CDBR-RC-Article 3.1 UNFCCC) was formally adopted. It has also been recognised that developed countries have had an obligation to lead and to provide finance and technology to developing countries (Article 4.7 UNFCCC). The Kyoto Protocol [35] further developed this approach. However, the rather rigid division between developed and developing countries made the system ineffective. The fact that the latter, in principle, would be obliged to act only if means of implementation were provided was a major obstacle to achieve the 'common objective' — to save the planet. However, as 'developing' countries economically grew and became more industrialised, it was crucial to build a new regime/approach based on the past experiences by 'adopting a more nuanced, diversified way of differential treatment' [36].

Although developed countries need to carry on leading, the Paris Agreement has adopted the principle of 'highest possible ambition' and 'progression' (Articles 3 and 4.3 UNFCCC), which enshrines a dynamic differentiation approach which 'aims to reflect the responsibilities, capacities, and circumstances of all parties'. The former principle means that countries need to strive for their highest possible ambition in a manner that their efforts reflect their common responsibilities, respective capabilities, and national circumstances. Along with this effort, it is crucial that countries go beyond their previous efforts every time they make a new commitment.

Although just transition is only enshrined in the preamble of the Paris Agreement, this new approach may be crucial for the implementation of just transition policies, particularly for workers' rights in middle-income and low-income countries. Developed countries' financial and technological contribution is essential in the adoption of just transition policies that should ensure that workers are not left behind. However, if no transfer takes place, countries must still elaborate and implement green and just transition policies to the best of their resources and capacities.

Argentina has reaffirmed, in its second NDCs, the principle of common but differentiated responsibilities and respective capabilities as enshrined in principle 7 of the 1992 Rio Declaration, Articles 3 and 4 of the UNFCCC, the preamble of the Paris Agreement, and on the 2019 Adaptation and Mitigation on Climate Change Act Law 27250 (hereinafter 'Climate Change Act'). Although the implementation of this NDC is not contingent on international cooperation, Argentina understands that the support of developed countries in the fulfilment of its national ambition will bring about significant benefits globally (Argentine NDCs 2020. p. 29).

Although Chile has not made any such statement on its second NDCs of 2020, there is no reason to argue that it does not share a similar view to Argentina's. Chile is also a party to the UNFCCC. Moreover, both Articles 2.2 and 4.3 of the Paris Agreement enshrine that the agreement, and particularly the NDCs, are to be applied in accordance with the principle of common but differentiated responsibilities and respective capabilities and considering national circumstances. 


\section{Argentine and Chilean Nationally Determined Contributions: Embedding Just Transition into the National Legal Orders}

\subsection{Chile's Second NDCs and Just Transition}

Chile officially submitted its updated NDCs, under the framework of the Paris Agreement, on 9 April 2020. In broad terms, this document intends to include more ambitious commitments for the country. They are structured in four components: mitigation; adaptation; integration; implementation measures (which includes capacity building, strengthening, and other subcomponents). Each component has specific goals and targets.

One of the most novel aspects of Chile's updated NDCs has been the incorporation of a social pillar on just transition and sustainable development. This pillar informs the four components of the NDCs. According to this social pillar, just transition and sustainable development, particularly the Agenda 2030, shall guide the development and implementation of every commitment incorporated in each of the NDC s' components. Consequently, the NDCs' commitments must take into consideration factors such as gender equality, the just transition of the workforce, and the rights of the most vulnerable people. Through this social pillar, Chile seeks to enhance the synergy between its climate commitments and the national environmental agenda, taking due consideration of the close link between climate and socio-environmental dimensions of climate change (Chilean NDCs 2020, p. 13, 23 and following).

Overall, Chile's NDCs approach issues concerning just transition from two perspectives. One of them is confined to the process of decarbonisation of the energy matrix launched in 2019 with the view to achieve carbon neutrality by 2050; the other is related to capacity building and strengthening.

In the first sense, the NDCs state that for the implementation of the social pillar, the design, application and monitoring of each commitment must take into account the following criteria: synergy with the SDGs; just transition; focused on the decarbonisation of the power generation matrix; gender equality and equity. Chile's specific contribution to just transition and sustainable development includes three commitments: (a) the application of the said four elements; (b) the establishment of a mechanism to monitor their application; (c) the development by 2021 of 'a Strategy for Just Transition that protects the rights of the most vulnerable in the process of decarbonising the energy mix, ensuring active participation of citizens in its design and implementation' (Chilean NDCs 2020, pp. 25-27).

Along these lines, in 2019 Chile launched a plan for the decarbonisation of the energy matrix. On 23 June 2020, the Ministries of Energy, Environment, and Labour and Social Security launched a process for the elaboration of a Strategy for Just Transition (See: https: / / www.youtube.com/watch?v=7fPAWUKCA4Q (accessed on 9 August 2021)) that will accompany the coal phase-out process with the closure of all plants in the country by 2040 [37].

As far as the contribution in capacity building and strengthening is concerned, Chile committed to develop, by 2020, a Strategy for 'Capacity Development and Climate Empowerment' to strengthen the sectoral, national, and subnational capacities of citizens and organisations, and to achieve national mitigation and adaptation targets. The Strategy will be developed and implemented considering the SDGs, as well as criteria of age, gender equity, and just transition, integrating knowledge and specific needs of vulnerable people. The elaboration and implementation of the 'Capacity Development and Climate Empowerment Strategy' shall promote "the elaboration, development and restructuring of labour competencies to mitigate GHG emissions and facilitate the adaptation to the impacts of climate change and measures adopted to fight it in the labour world, decreasing the negative effects and taking advantage of opportunities that may arise. Likewise, they shall promote the design and implementation of training programmes on environmental and climate change for actors holding key functions at sectoral, national and subnational levels" (Chilean NDCs 2020, p. 75). Many of such training programmes are currently offered by the National Training and Employability Service-SENCE. 


\subsection{Argentina's Second NDCs and Just Transition}

Argentina, as a developing country and vulnerable to the impact of climate change impacts, has the responsibility to promote concrete actions and policies to attain an inclusive and balanced sustainable development model.

In December 2020, Argentina presented its second NDCs, which have set out the general objectives for the protection of the environment by 2030. To do so, Argentina embraces the concept of equity, justice, and highest ambition in light of national circumstances. Specifically, Argentina has adopted just transition as a guiding principle in the second NDCs (Argentine NDCs 2020, p. 39).

\subsubsection{Just Transition and Workers' Rights}

Argentina considers the economic and social impact of the second NDCs adaptation and mitigation measures to guarantee a just transition. It is crucial to consider the specific needs and concerns of developing countries in line with article 4.8 of the UNFCCC and Article 4.15 of the Paris Agreement (Argentine NDCs 2020, p.23).

Argentina's commitment contemplates the eradication of poverty through the promotion of just transition. It aims to address the needs of the entire population and to guarantee integrated and sustainable development without affecting future generations. The reduction in labour informality is a key goal to guarantee human development (Argentine NDCs 2020, p. 19). Furthermore, strengthening the promotion of sustainable jobs, the production of information related to climate change decision-making and its impact upon different economic sectors constitute major guiding principles of these NDCs. Similarly, the implementation of skills policies for professional development is another key principle.

It emphasises the importance of decent work, sustainable jobs, and the need for training and acquisition of new skills for new jobs. It also highlights the relevance of the circular, social, and informal economy to attain the goal of sustainable development. This approach entails implicitly the obligation to achieve a development that considers the protection of vulnerable people (Argentine NDCs 2020, p. 26).

The health of workers is another key aspect that may be severely affected, particularly those who work outdoors. In the same vein, new occupational diseases may emerge, which along with the existing ones, may constitute a crucial challenge in the protection of health and safety at work (Argentine NDCs 2020, p. 26).

These measures constitute a very comprehensive approach of what just transition is and how it can benefit the workers. Although its impact remains to be seen, this seems an encouraging start.

\subsubsection{Transversal Approach}

These NDCs adopt a transversal approach, which is reflected in both the measures considered necessary to fight climate change and the governance mechanism. It is essential to acknowledge the structural conditions based on gender, social dimension, ethnic groups, age, and religion, amongst others, that have an impact on the construction and determination of vulnerabilities and capacities. (Argentine NDCs 2020, p. 46).

Given their vulnerability and their limited participation in decision-making processes and considering that they are overrepresented in the informal economy and unemployment rate, Argentina will pay special attention to women, minorities, young people, indigenous people, and disabled people. Better access to financial and technological resources, as well as skills training programmes, may allow them to adapt to climate change. Argentina will promote the development of necessary skills, so workers can keep their jobs and even further progress when they have been transformed and have become more sustainable (Argentine NDCs 2020, p. 23).

This transversal approach includes specifically a gender dimension, which is crucial in developing countries to protect women's rights. Higher unemployment rate, wage inequality, as well as the participation in less 'productive' jobs put women in a more vulnerable 
situation when facing the risks and disasters caused by climate change (Argentine NDCs 2020, p. 46).

This transversal approach is also essential to ensure that just transition policies do not only work for those who are in full-time jobs, but it also considers those in part-time jobs, the informal economy and non-productive jobs, which are a significant part of the Argentine labour market.

\subsubsection{Limited Resources and a Global Challenge}

As established in Article 4.9 of the Paris Agreement and in accordance with the Climate Change Act, these second NDCs will be updated every 5 years, pursuing a continuous improvement process in terms of accuracy, transparency, and robustness of information related to climate change policies.

In this quest, though, the financial element constitutes one the biggest challenges to ensure the effective implementation of climate action at both the national and global levels. Specifically, international cooperation is central in areas such as skills development and the funding and transfer of technology to adopt mitigation and adaptation measures to fight climate change (Argentine NDCs 2020, p. 23).

Although the implementation of these NDCs is not contingent on international cooperation, Argentina considers that the support of developed countries in the fulfilment of its national ambition would bring about significant benefits globally (Argentine NDCs 2020, p. 29). That being said, limited resources, weak monitoring bodies, incompatible collection, and data handling systems related to climate change, limited access to information, as well as limited human resources may certainly constitute a serious obstacle to attain this objective by 2030 and, consequently, to successfully achieve a just transition. International solidarity, particularly regarding funding as well as technology, will be crucial for Argentina and other developing countries to successfully reduce its emissions and protect workers' rights.

These second NDCs are a milestone in the pursuit of just transition towards a resilient, sustainable, solidary, inclusive, and innovative country which aims to go carbon neutral by 2050 where none of its citizens is left behind. This action may entail a structural productive change whose main objective is economic recovery, employment creation, and the enhancement of national production economic competitiveness within the framework of just transition. Such a herculean task requires significant resources that today are limited. In this respect, international solidarity will be crucial.

\section{Just Transition Governance and Workers' Rights}

\subsection{Inter-Ministerial Public Bodies}

\subsubsection{Argentine Inter-Ministerial Public Bodies}

Given the severity and urgency to tackle climate change, Argentina has adopted a multidimensional and transversal type of governance, which aims to bring about a radical change of the development paradigm. In this respect, it has decided to create several inter-ministerial public bodies to elaborate and implement coherent and consistent public policies. The inclusion of social partners in this institutional dialogue is another major feature of this system.

This is reflected in the second NDCS in which both institutional bodies, social partners, and the general public have played a major role in their development (Argentine NDCs 2020, p. 29). This is crucial to fight climate change in Argentina for two reasons: firstly, it guarantees the elaboration and implementation of consistent public policies in the short-, medium-, and long-term. Secondly, it ensures that every province's interests-Argentina is a federal country - as well as social partners and civil society are also considered in the design of climate change public policies.

In this respect, the Climate Change Act (Articles 7-11 Law 27250) has created the National Cabinet of Climate Change (Gabinete Nacional de Cambio Climático), whose chair is the Chief of the Cabinet of Ministers-which has similar features to a prime minister 
in a presidential system. Furthermore, it has adopted a 'Ministers Meeting' (Reunión de Ministros), which ensures that ministers from all the relevant areas participate and design climate change policies. The 'Focal Points Table' (Mesa de Puntos Focales), which includes political representatives and technical civil servants of the national government, has been created to guarantee a relevant dialogue between the technical and political teams.

Furthermore, the federal nature of Argentina can constitute a big challenge in terms of elaboration and implementation of just transition policies. The constitutional order gives the federal government limited powers to set up national framework policies. Provinces have the power to further elaborate and properly implement these federal policies and norms. In this respect, the 'Provincial Coordination Table' (Mesa de Articulación Provincial) has been included in this institutional design to consider the provinces' interests and to effectively elaborate subnational climate change plans.

This constitutes a positive first step in ensuring the representation of the different public bodies, which may simplify the consideration of just transition when designing and implementing environmental policies. However, given the recent nature of the legislation, the effectiveness of these bodies as well as the role of provinces in the realm of just transition remain to be seen.

\subsubsection{Chilean Inter-Ministerial Public Bodies}

In Chile, climate change issues fall within the mandate of the Ministry of Environment [38]. In January 2020, it submitted a Climate Change Framework bill to be discussed in the Chilean Congress [39]. It is within this framework that the Ministry of Environment developed and submitted Chile's updated NDCs.

On 23 July 2020, the Ministers of Energy, Labour and Social Security, and Environment launched the process of elaboration of the Strategy, in a virtual ceremony where governmental agencies, ILO representatives, employers, workers, civil society and academia actively participated and put forward their views and projects [40].

The Strategy for Just Transition is a joint proposal of the Ministries of Energy, Labour and Social Security and Environment. Its general objective is to phase out coal-fired power plants by 2040. In doing so, it seeks to ensure that the energy transition to carbon neutrality integrates a just and equitable environmental and social development, promoting the creation of green jobs that improve the living standard of people, and improving the environmental conditions in the areas where the energy infrastructure is located. Likewise, the Strategy seeks to draft an initial proposal, with the involvement of relevant stakeholders from the public and private sector, civil society and academia and, ultimately, adopt its text through a process of public consultation. Currently, the Strategy is at the public consultation stage. The Strategy acknowledges that this will present environmental benefits, but it will also have negative impacts on employment. Overall, nearly 4.400 jobs will be lost, and 9.500 whose jobs are indirectly related to the coal-fired power plants' activities will be affected. At the local level, the Strategy includes the development and implementation of Local Action Plans in those areas where coal-fired power plants are located. The construction of such plans must take into consideration the job losses, the relevant communities, environmental, and health needs, among others [41].

As for the Strategy's Governance, the Working Plan considers an Inter-ministerial Committee composed of the Ministry of Energy, Ministry of Environment, and Ministry of Labour and Social Security and other relevant governmental agencies. It includes an Executive Committee, whose Executive Secretariat is the Ministry of Energy, and count with the participation of other Ministries and governmental agencies, communities, trade unions, business, and other international entities such as the Deutsche Gesellschaft für Internationale Zusammenarbeit (GIZ), the Economic Commission for Latin America and the Caribbean (ECLAC), and the Inter-American Development Bank (IADB). Finally, at the local operational level, there is a local committee composed by local representatives, public bodies, and companies [42]. 


\subsection{Social Dialogue}

Unions have traditionally played a role in managing how capital owners try to make profit. Unsurprisingly, it has been a rather conflictive, and sometimes cooperative, relationship. As pointed out by Galgóczi, decarbonisation constitutes a 'shared objective in the interest of humanity'. This is a significant challenge for unions because they seem to now have two crucial roles to play. Traditionally, unions defend workers' interests and rights. However, decarbonisation and the technological revolution require the active intervention of unions, too. The protection of workers' rights in the context of just transition requires the coordination of trade unions, as environmental actors, as well as public bodies to ensure the implementation of green policies that protect both the planet as well as workers and their communities.

\subsubsection{Social Dialogue in Developing Countries}

Social dialogue is crucial around the globe in the development of climate change policies that ensure the implementation of NDCs and the effectiveness of just transition policies. The ILO's just transition guidelines (2015) have recognised the importance of social dialogue at different levels. Whilst governments must promote social dialogue at all stages when implementing green and just transition policies, social partners play a key role in elaborating and implementing just transition policies. Whilst national and sectoral unions may be able to influence and shape the green and just transition agenda, local or enterprise unions may play a more important role in the implementation stage [43].

Along with these challenges, there are three specific issues that Global South countries face. Firstly, in a post-COVID period, developing countries aim to create employment, regardless of its green nature, as soon as possible. This constitutes a risk because just transition policies may be overshadowed by high unemployment rates. Secondly, the high percentage of informality in the Argentine and Chilean labour markets-similar to other developing countries - means that not only traditional trade unions should be part of the process, but de facto unions or leaders that tend to represent informal workers or those who fall in a grey category, such as those considered as 'independent contractors'. Secondly, another risk is the lack of social dialogue tout court. In this regard, it is necessary to adopt local strategies that fit the circumstances and needs of each country and community. The participation of civil society, either through NGOs, professional bodies, or local authorities may be a solution in those sectors where workers' representation is rather limited or non-existent.

\subsubsection{Argentine Social Partners' and Civil Society's Participation}

The multidimensional and transversal approach requires the adoption of an appropriate governance system that can guarantee that all voices are heard. It is also crucial that all policies are coherent and consistent with the objectives set out in the NDCs. In this respect, Argentina has included social partners and civil society in some of its institutional bodies.

Firstly, the 'Enlarged Table' (Mesa Ampliada) is a body under the Climate Change Cabinet, in which the opinions and interests of diverse sectors and actors are considered. Civil society, scientists, universities, employers' organisations, professional bodies, municipalities, political parties, indigenous communities, and trade unions can actively participate and make their contributions to climate change policies. Any citizen can also contribute to them by using the online Civic/Civil Society Participation Mechanism through which they can share their views and suggestions to the Climate Change Cabinet.

Secondly, Argentina has created an Advisory Council (Consejo Asesor, Articles 12-15 Law 27250) as a permanent external body to advise the Climate Change Cabinet in the development of climate change public policies. Similar to the 'Enlarged Table', this body includes scientists and researchers, environmental NGOs representatives, trade unions, indigenous communities, universities and academic institutions, businesses, public and private research centres, as well as political parties. Major Argentine trade unions have been very active in voicing their concerns and the importance of leaving no worker behind 
in this context of just transition [44]. Their participation in these bodies will be crucial to achieve such objectives.

In the last decade, Argentine social partners, particularly trade unions, have expressed their concerns and interests in green policies and just transition. Back in 2015, the three biggest Argentine trade union confederations, CGT (Confederación General del Trabajo), CTA-A (Central de Trabajadores Argentinos-Autónoma), and CTA-T (Central de Trabajadores Argentinos-Trabajadores) adopted fourteen commitments regarding climate change, such as the elaboration and implementation of an energetic plan that ensures the use of renewables energies. It also included a reform of transport of passengers and freight. From a procedural point of view, it was considered necessary to foster the creation of democratic mechanisms where unions can participate actively in the elaboration of public policies. They also argued for the inclusion of just transition as a guiding principle in every public policy [45]. Peronism, Argentina's ruling party, is currently navigating between traditional productivism as a development strategy and environmental awareness. Trade unions, traditionally linked to Peronism, have considered that job creation should be the priority in a post-pandemic world. They have also accepted that it is necessary to respect the environmental commitments in the NDCs. However, they have pointed out that their participation in the elaboration and implementation of the NDCs policies is crucial [46].

Trade unions have not confined their participation to these institutional bodies. Some major trade unions, such as UOCRA (Argentine Building Workers Union), SMATA (Mechanic and Automotive Transport Union), and Camioneros (Argentina Truck Drivers Union), have drafted an ambitious development plan for Argentina in a post-pandemic world, where productivism and transition towards a green economy are amongst its guiding principles. Moreover, they consider informal economy (economía popular) and family farming constitute two key areas that need to be reformed to meet the green standards as well as the urgent needs of a post-pandemic recovery [47]. Since the pandemic is not finished, their effectiveness remains to be seen.

Finally, although trade unions seem to have been relatively active, Argentina will incorporate by 2030 the environmental dimension in collective bargaining in legislation as well as in enforcement protocols of workers' protection. It will also include it in employment programmes to ensure the creation of new sustainable and decent jobs (Argentine NDCs 2020, p. 23).

\subsubsection{The Limited Role of Chilean Social Partners}

Chile's Strategy for Just Transition ensures public participation in decision-making processes on just transition matters. The governance structure of the Strategy includes three bodies, two of which (the Executive and the Local Committee) are composed of representatives of the State, local communities, trade unions, businesses, academia, NGOs and civil society, and other international groups. Therefore, the drafting of the Strategy has been made with the participation of these non-state actors. Furthermore, the final draft must be submitted for public consultations before its adoption.

Another body where tripartite social dialogue on issues concerning just transition can take place in Chile, is the 'Consejo Superior Laboral' (Higher Labour Council). This is a tripartite advisory body, whose role is, inter alia, to collaborate in the development of public policies aimed at reinforcing and promoting social dialog and to suggest initiatives aimed at creating jobs. The Council has nine members, three of them are appointed by the Government, three by the most representative organisation of employers, and three by the most representative trade unions [48].

\section{Conclusions}

Just transition seems to be the only pathway to ensure that nobody is left behind, particularly workers. However, the content and methodology of domestic policies that aim to bring forward green and just transition policies may vary significantly from one country to another. In this respect, it is essential to explore how Global South countries, 
which navigate through the urgency of constantly creating new jobs-either green or not, and the need to protect the environment, will square that circle.

Developing countries may find it unfair that they are not able to exploit their natural resources while some developed countries have done it for more than a century, particularly in a region such as South America, which has been 'blessed' with generous resources. This is all the more true given the 'fourth-generation' extractivism that some Latin American countries may pursue. In this regard, the adoption of a 'dynamic differentiation' approach in the Paris Agreement may constitute a step forward in the relationships between developed and developing countries. By adopting a more nuanced approach, developing countries are still entitled to be provided with financial and technological help, whilst still being obliged to contribute unconditionally to the protection of the environment to the best of their capacities.

In this context, the adoption of the second NDCs by Chile (March 2020) and Argentina (December 2020) has constituted a first step in the embedding of just transition in their domestic legal orders. This is crucial, because under the auspices of the Paris Agreement both countries have committed to international legally binding obligations to respect the content of their respective NDCs. The question arose as to whether these NDCs followed the 2015 Just Transition Guidelines, which are the key measure to protect workers' rights when implementing just transition policies. Its inclusion with a particular focus on workers and the reform of the labour market aims to guarantee that no one is left behind and countries include measures that alleviate the negative socio-economic impact that some green policies may have. Both countries have also paid attention to the acquisition of new skills to make workers more employable.

The elaboration and implementation of comprehensive and consistent green and just transition policies requires fluid communication amongst the different agencies of national governments. The adoption of inter-institutional bodies in Argentina and the proposed reform in Chile seem to go in the right direction. Furthermore, dialogue with private actors such as trade unions, professional bodies, scientists, academics, NGOs, and civil society, particularly organisations that represent informal workers, is necessary to have a comprehensive understanding of the issues at stake. The inclusion of social partners in two Argentine institutional bodies is a good step in this regard. Although they have elaborated some interesting proposals, unions need to play a more active role to ensure that just transition protects workers' rights when implementing and designing mitigating and adaptation plans. They also need to participate and be proactive in terms of job creation and the development of green markets.

Both Argentine and Chilean NDCs seem to have followed the requirements spelled out by the ILO 2015 guidelines. Nonetheless, the role of NDCs in the elaboration and implementation of just transition policies and the protection of workers' rights remains to be seen. The next decade will be crucial to ensure that the attainment of environmental goals does not come at the price of workers.

Author Contributions: All authors have contributed equally to every section of this paper, except for Sections 5.2, 6.1.1, 6.2.1 and 6.2.2 and the reference and edition where the contribution of M.P. was 70\%, and C.Á.A. and P.S.S.-15\% each; and Sections 5.1, 6.1.2 and 6.2.3 where the contribution of P.S.S. was 70\%, and C.Á.A. and P.S.S.-15\% each. All authors have read and agreed to the published version of the manuscript.

Funding: This research was funded by Kingston University London.

Institutional Review Board Statement: Not applicable.

Informed Consent Statement: Not applicable.

Data Availability Statement: The study did not report any data.

Conflicts of Interest: The authors declare no conflict of interest. 


\section{References}

1. Räthzel, N.; Uzzell, D. Mending the breach between labour and nature: Environmental engagements of trade unions and the North-South divide. Interface 2012, 4, 81-100.

2. Singh Ghaleigh, N. Just Transitions for Workers: When Climate Change Met Labour Justice, Research Paper Series No 2019/30; School of Law University of Edinburgh: Edinburgh, UK, 2019.

3. Chancel, L.; Piketty, T. Carbon and Inequality: From Kyoto to Paris; Paris School of Economics: Paris, France, 2015. [CrossRef]

4. Johnstone, P.; Hielscher, S. Phasing out coal, sustaining coal communities? Living with technological decline in sustainability pathways. Extr. Ind. Soc. 2017, 4, 457-461. [CrossRef]

5. Stevis, D.; Morena, E.; Krause, D.A. Introduction: The genealogy and contemporary politics of just transitions. In Just Transitions. Social Justice in the Shift towards a Low-Carbon World; Morena, E., Krause, D., Stevis, D., Eds.; Pluto Press: London, UK, 2020; pp. 32-55.

6. Nationally Determined Contributions (NDCs) Are at the Heart of the Paris Agreement and the Achievement of These Long-Term Goals. NDCs Embody Efforts by Each Country to Reduce National Emissions and Adapt to the Impacts of Climate Change. The Paris Agreement (Article 4, Paragraph 2) Requires Each Party to Prepare, Communicate and Maintain Successive Nationally Determined Contributions (NDCs) That It Intends to Achieve. Parties Shall Pursue Domestic Mitigation Measures, with the Aim of Achieving the Objectives of Such Contributions. Available online: https://unfccc.int/process-andmeetings/the-paris-agreement/nationally-determined-contributions-ndcs/nationally-determined-contributions-ndcs\#: \{\}: text=Nationally $\% 20$ determined $\% 20$ contributions $\% 20(\mathrm{NDCs}) \% 20$ are, the $\% 20 \mathrm{impacts} \% 20 \mathrm{of} \% 20 \mathrm{climate} \% 20$ change (accessed on 9 August 2021).

7. ILO. Guidelines for a Just Transition towards Environmentally Sustainable Economies and Societies for All; ILO: Geneva, Switzerland, 2015. Available online: https://www.ilo.org/wcmsp5/groups/public/---ed_emp/---emp_ent/documents/publication/wcms_ 432859.pdf (accessed on 9 August 2021).

8. Chilean Updated NDCs. Submitted in April 2020. Available online: https://www4.unfccc.int/sites/ndcstaging/ PublishedDocuments/Chile\%20First/Chile\%27s_NDC_2020_english.pdf (accessed on 9 August 2021).

9. Second Argentine NDCs Submitted in December 2020. Available online: https://www4.unfccc.int/sites/ndcstaging/ PublishedDocuments/Argentina\%20Second/Argentina_Segunda\%20Contribuci\%C3\%B3n\%20Nacional.pdf (accessed on 9 August 2021).

10. Argentine and Chilean NDCs Are the First Latin American Countries to Have Enshrined Just Transition in Their Second NDCs. Costa Rica, Colombia and the Dominic Republic Have Also Included It Late 2020 in Their Updated Version of the First NDCs. Available online: https://www4.unfccc.int/sites/NDCStaging/Pages/All.aspx (accessed on 9 August 2021).

11. Van, H. Legal Doctrine: Which Method(s) for What Kind of Discipline. In Methodologies of Legal Research; Van, H., Ed.; Hart Publishing: Oxford, UK, 2013; p. 17.

12. Hutchinson, T. Doctrinal Research. In Research Methods in Law; Watkins, D., Burton, M., Eds.; Routledge: New York, NY, USA, 2013; p. 11.

13. Nelken, D. Comparative Law and Comparative Legal Studies. In Comparative Law. A Handbook; Örücü, E., Nelken, D., Eds.; Hart Publishing: Oxford, UK, 2007; p. 34.

14. Rosemberg, A. Strengthening Just Transition Policies in International Climate Governance. Policy Analysis Brief, Stanley Foundation. 2017. Available online: https://stanleycenter.org/publications/strengthening-just-transition-policies-in-internationalclimate-governance/ (accessed on 22 March 2021).

15. Measuring the Socio-Economic Footprint of the Energy Transition: The Role of Supply Chains; International Renewable Energy Agency: Abu Dhabi, United Arab Emirates, 2019; p. 18.

16. Ana Belén Sánchez and Braulio Torres, Una Recuperación Verde y Justa en América Latina y el Caribe: Una Perspectiva Desde el Mundo del Trabajo. Available online: https://www.ilo.org/wcmsp5/groups/public/---americas/---ro-lima/documents/ publication/wcms_763724.pdf (accessed on 9 August 2021).

17. BID. CEPAL y WWF. El Desafío Climático y de Desarrollo en América Latina y el Caribe. Opciones para un Desarrollo Resiliente al Clima y Bajo en Carbono. 2014, p. 14. Available online: https://publications.iadb.org/publications/spanish/document/ El-desaf\%C3\%ADo-clim\%C3\%A1tico-y-de-desarrollo-en-Am\%C3\%A9rica-Latina-y-el-Caribe-Opciones-para-un-desarrolloresiliente-al-clima-y-bajo-en-carbono.pdf (accessed on 9 August 2021).

18. OIT. Nota Técnica Regional, Panorama Laboral en Tiempos de la COVID-19, Una Recuperación Verde y Justa en América Latina y el Caribe: Una Perspectiva Desde el Mundo. p. 2. Available online: https://www.ilo.org/wcmsp5/groups/public/---americas/ ---ro-lima/documents/publication/wcms_763724.pdf (accessed on 9 August 2021).

19. OIT. Panorama Laboral 2019 [Recurso Electrónico]: América Latina y el Caribe/Organización Internacional del Trabajo, Oficina Regional para América Latina y el Caribe. Available online: https://labordoc.ilo.org/discovery/delivery/41ILO_INST:41ILO_ V2/1275169440002676?lang=es (accessed on 9 August 2021).

20. Anigstein, C.; Wyczykier, G. Union Actors and Socio-environmental Problems. The Trade Union Confederation of the Americas. Latin Am. Perspect. 2019, 46, 109-124. [CrossRef]

21. ILO. COVID-19 y el Mercado de Trabajo en Argentina. Available online: https://www.ilo.org/wcmsp5/groups/public/--americas/---ro-lima/---ilo-buenos_aires/documents/publication/wcms_754621.pdf (accessed on 9 August 2021). 
22. Instituto Nacional de Estadísticas INE. Tasa Ocupacional Informal Nacional en el trimestre Movil (20 December 2020-21 February 2021). Available online: https://www.ine.cl/estadisticas/sociales/mercado-laboral/informalidad-laboral (accessed on 9 August 2021).

23. OIT. Panorama Laboral 2019. pp. 78-80. América Latina y Caribe. Available online: https://www.ilo.org/americas/ publicaciones/WCMS_732198/lang--es/index.htm (accessed on 9 August 2021).

24. OIT. Panorama Laboral 2020. América Latina y Caribe. Available online: https://www.ilo.org/wcmsp5/groups/public/--americas/---ro-lima/documents/publication/wcms_764630.pdf (accessed on 9 August 2021).

25. OIT. El Empleo en un Futuro de cero Emisiones Netas en América Latina y el Caribe, El Empleo en un Futuro de cero Emisiones netas en América Latina y el Caribe. p. 21. Available online: https://www.ilo.org/wcmsp5/groups/public/---americas/---rolima/documents/publication/wcms_752078.pdf (accessed on 9 August 2021).

26. Interim Report of the Special Rapporteur on Extreme Poverty and Human Rights, Olivier De Schutter The "Just Transition" in the Economic Recovery: Eradicating Poverty within Planetary Boundaries. UNGA, (A/75/181/Rev.1), Para.8. Available online: https:/ / www.undocs.org/A/75/181/REV.1 (accessed on 9 August 2021).

27. Green Jobs: Towards Decent Work in a Sustainable, Low-Carbon World. Available online: https://www.ilo.org/wcmsp5/groups/ public/---ed_emp/---emp_ent/documents/publication/wcms_158727.pdf (accessed on 31 March 2021).

28. ILO. World Employment Social Outlook 2018, Greening with Jobs. pp. 1-4. Available online: https://www.ilo.org/wesogreening/documents/WESO_Greening_EN_web2.pdf (accessed on 9 August 2021).

29. See Paris Agreement Preamble. Available online: https://unfccc.int/sites/default/files/english_paris_agreement.pdf (accessed on 9 August 2021).

30. Paris Agreement, Article 2. Available online: https://unfccc.int/sites/default/files/english_paris_agreement.pdf (accessed on 9 August 2021).

31. Paris Agreement, Article 4. Available online: https://unfccc.int/sites/default/files/english_paris_agreement.pdf (accessed on 9 August 2021).

32. Bodansky, D.; Brunnée, J.; Rajamani, L. International Climate Change Law, 1st ed.; Oxford University Press: Oxford, UK, 2017 ; p. 231.

33. Rajamani, L. Differential Treatment in International Environmental Law; Oxford University Press: Oxford, UK, 2006.

34. Rio Declaration on Environment and Development. In Proceedings of the UN Conference on Environment and Development, Rio de Janeiro, Brazil, 3-14 June 1992; UN Doc. A/CONF.151/26 (Vol. I), 12 August 1992.

35. Kyoto (Japan), 11 December 1997, in force 16 Feb. 2005. Available online: https://unfccc.int/resource/docs/convkp/kpeng.pdf (accessed on 9 August 2021).

36. Voigt, C.; Ferreira, F. 'Dynamic Differentiation': The Principles of CBDR-RC, Progression and Highest Possible Ambition in the Paris Agreement. Transnatl. Environ. Law 2016, 5, 285-303. [CrossRef]

37. Available online: https://energia.gob.cl/noticias/nacional/gobierno-inicia-proceso-para-transicion-justa (accessed on 9 August 2021).

38. Ley N $\mathrm{N}^{\circ} 19.300$ Sobre Bases Generales del Medioambiente. Article 70, Para.h. Available online: https://www.bcn.cl/leychile/ navegar?idNorma=30667 (accessed on 9 August 2021).

39. Available online: http:/ /leycambioclimatico.cl/wp-content/uploads/2020/07/ProyectoLeyCC_13012020.pdf (accessed on 9 August 2021).

40. Available online: https://www.youtube.com/watch?v=7fPAWUKCA4Q (accessed on 9 August 2021).

41. Available online: https://energia.gob.cl/mini-sitio/ estrategia-de-transicion-justa-en-energia (accessed on 9 August 2021).

42. Available online: https://energia.gob.cl/sites/default/files/ministro_de_energia_webinar_transicion_justa.pdf (accessed on 9 August 2021).

43. Galgóczi, B. Just transition on the ground: Challenges and opportunities for social dialogue. Eur. J. Ind. Relat. 2020, 26, 367-382. [CrossRef]

44. Confederación General del Trabajo (CGT). Available online: https:/ /www.cgtrainternacional.com.ar/?s=temas\&sub=cambioclimatico (accessed on 9 August 2021).

45. Available online: http://www.ctainternacionales.org/cambio-climatico-no-hay-trabajo-en-un-planeta-muerto/ (accessed on 9 August 2021).

46. Available online: https://www.equaltimes.org/argentina-at-an-energy-crossroads\#.YLS4V5NKhhE (accessed on 9 August 2021).

47. Available online: https://plandesarrollohumanointegral.com.ar/plan-desarrollo.pdf (accessed on 9 August 2021).

48. Ley 20.940, que Moderniza el Sistema de Relaciones Laborales. Article 4 and Subsequents. Available online: https://www.bcn.cl/ leychile/navegar?idNorma=1094436 (accessed on 9 August 2021). 